事前学習のためのマルチメディアマニュアル作成・提示システム

Multimedia Manual Authoring and Presentation System for Preparedness Learning

\title{
○北島宗雄, 島田英昭（産業技術総合研究所）
}

Muneo Kitajima and Hideaki Shimada,

National Institute of Advanced Industrial Science and Technology (AIST)

\section{1 はじめに}

日常生活において、我々は、次に何が起こりそうかというこ とについて事前に予測を立て、何を行うのが最も道切であるか の判断を行いながら行動をすることが多い。緝り返し行われる 行野については、それら一連の行動が手䌇き的知識（あるいは、 手順) として確立されていて、それを活性化することによって、 ひとつのパッケージになって、系列的に実行される。しかし、ま れにしか行われない行動や、全く行ったことのない行動にうい ては、そのような知識は存在しないので、逐次、暗切な行動を見 つけながら、行動を行わなければならない。本稿では、後者の 事態に備えて、手順を事前に学習することを支援するマニュア ルを作成・提示する技術、ならびに、その応用事例を報告する。

\section{SMMAPS}

我々は、手順を学習者に理解しやすい表現で提示する「手 順学習のためのマルチメティアマニュアル作成・提示システム "SMMAPS ( cenario-based Multimedia Manual $\underline{\text { A uthoring }}$

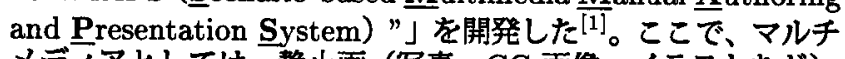
メディアとしては、静止画 (写真、CG 画像、イラストなど)、 動画 (手話、ジェスチャ、注意唤起効果など)、文字 (説明文な そ)、音(ナレーション、効果音など)が含まれる。マニュアル を作成する際には、シテリ才を設定し、それを一連の場面に展 開する。そして、学習者の個人特性や、状況经合わせて、上記 マルチメティアを組み合わせて場面を具体的に表現する。以下 に、SMMAPSによって作成したマニュアルを 2 例、紹介する。

\section{SMMAPS の応用事例}

災䒠避嚾マニュアル：Fig.1に、SMMAPSにより作成した災 害避難マニュアルの 1 場面を示す $[1]$ 。提示内容は、災害時の様 子をリアルに表現するCGレンダリングされた画像 (崖崩れ)、 その場所での注意事項を記した字幕（摆れを感じたら、すぐに 壁から離れましょう)、字幕を読みあげるナレーショシ、崖の場 所を示す地図、崖に注意を向けさせる注意喚起効果（黄色い枠 のズーム・回転)、手話である。実際の教示場面では、避難シナ リオに治って、ここで示したような場面か、連続提示される。

このマニュアルは、SMIL(Synchronized Multimedia Integration Language)により記述され、アクセシビリティへ の配慮がなされている。また、学習者として想定される人が住 んでいる場所に合わせて災害避難シナリオを作成している。こ れにより、個々の学習者が、自身の問題として具体的に災害時 避難手順を学習できるようにしている。さらに、個々の学習者 の認知特性に合わせて、情報提示方法を変更できる。たと元 ば、手話 (有/無)、絵文字 (有/無)、ナレーション速度 (普 通/ゆっくり) を設定できる。

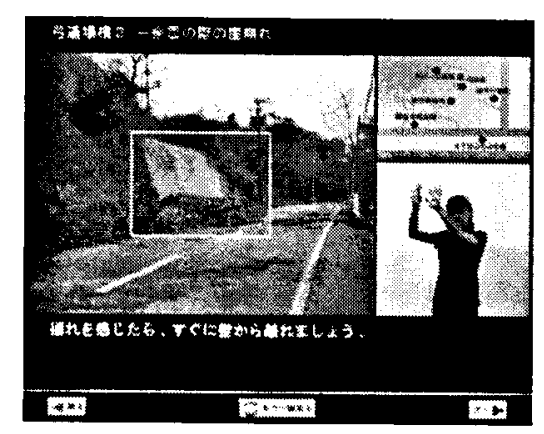

Fig 1: A multimedia disaster evacuation manual
通学路の前学習 : Fig.2 に、SMMAPS により作成した通 学路事前学㽝マニュアルの 1 場面を示す到。このマニュアルは、 新入生である学習者 (男児)が1 人で通学できるようにしたい という保護者の二ーズにこたえることを目的として作成した。 場面には、学習者の生活環境に合わせ、実際の通学路の写真や 100 商店 (学習者が知っている店舗) の前です」といった字尊 を插入した。また、注意喚起奻果は、心理学的にその有妙性を 確㒛したフラッシュ矢印、スーム枠を利用した ${ }^{[3]} 。 3$ 回の学習 セッション後に実施した涉行テストでは、「交差点です。気をつ けて渡りましょう。」などの字幕の諜を、同行した研究スタッ フ・母親に報告することが認められたり、先頭に立って学校ま での経路を歩行していたことから、マニュアルによる学習が有 効であったことが確認された。

\section{4 おわりに}

自然災害等の非日常的な事態や初めて経験する事態に遭遇し たとき、個人個人の頭に何を行うべきかということに関する知 識が事前に十分刷り込まれていることが、個人のレベルでの安 心安全を礁保するための必要条件である。本稿では、SMMAPS に基づくことにより、個人特性の多棣性、起こり得る事態の多 様性に対応した、暗切な手顺の獲得を支援するマニュアルが作 成できることを、2つの事例を举げて示した。

付記本研究は、文部科学省科学技術振興調整費「障害者の 安全で快適な生活の支援技術の開発一認知・知的障害者の理解 特性に合わせた情報提示技術の開発」の一環として行われた。 参考文献

[1] Shimada, H. \& Kitajima, M.: SMMAPS: Scenariobased multimedia manual authoring and presentation system and its application to a disaster evacuation manual for special needs; Proceedings of CHI2006 conference on human factors in computing systems, pp.13131318 (2006).

[2] 島田英昭・北島宗雄 - 奈良雅子:SMMAPS に上る小学校新 入生の通学路の学習教材の作成と評価;ヒューマンインタ フェースシンボジウム発表論文集 (明刷中).

[3] Masakura, Y., Nagai, M., \& Kumada, T.: Effective visual cue for guiding peoples' attention to important information based on subjective and behavioral measures; Proceedings of the first international workshop on kansei, pp.125-128 (2006).

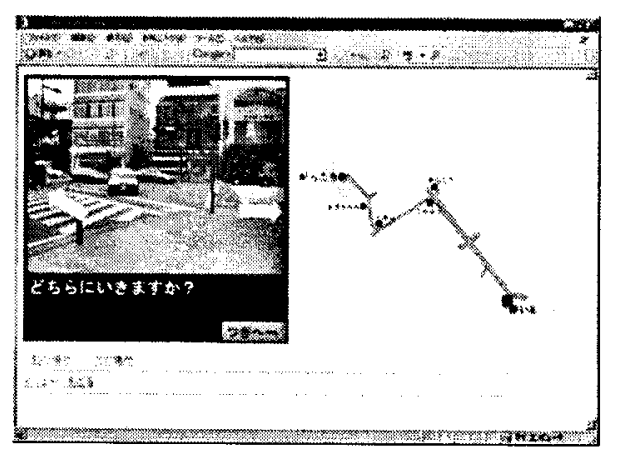

Fig 2: A manual for learning how to go to school 